\title{
Armed Forces and Disaster Management in India
}

\author{
Ganesh Kumar ${ }^{1 *}$ and Brigadier Ravi Dimri ${ }^{2}$ \\ ${ }^{1}$ Department of Economics, Army Cadet College, Indian Military Academy, Dehradun, India \\ ${ }^{2}$ Commander, Army Cadet College, Indian Militaty Academy, Dehradun, India \\ *Corresponding author: saini_ganesh@rediffmail.com
}

\begin{abstract}
Currently, involvements of armed forces to aid civil authority in various events are continuously rising. Given their professional training and spirit to deliver and assist the communities, the armed forces always become the first choice of any state civil authorities in the event of disasters. The role of the armed forces in disaster management is globally well recognized. Their ability to work under adverse ground and climatic conditions is an unusual attribute to help to civil authority during disasters. Government, civil society and all other stakeholders have incredible faith and believe that all types of disaster can be efficiently handled by the armed forces. The Indian armed forces are one of the most dedicated professional and modernized armed forces in the world. They are always in a state of operational readiness to move quickly to any disaster affected area. Besides, NDRF also played an important role in rescue and relief operation in all major disasters in the country; in fact their service during the disasters reduces the pressure on the armed forces. The armed force will continue to play a vital role in disaster response as they are the core of the government's response capacity in major disaster situations.
\end{abstract}

Keywords: Disaster Management, Armed Forces, Civil Administration and NDRF

Disaster management is a continuous and integrated process involving many stakeholders working together to prevent, mitigate, prepare for, and respond to disaster and reconstruction after disaster. It is confirmed that no single organization can handle a disaster situation of any scale alone. It is the collective responsibility of different groups of stakeholders, like various ministries, departments and boards of union, state and local governments, private sector, civil society, Non- Governmental Organizations (NGO), armed forces, Central Armed Police Forces (CAPF), National Disaster Response Force (NDRF) and international institutions etc., and everyone plays different roles in this process. While, some stakeholders have to take a leading role in disaster management, others play a supporting role in this process. Thus, there are different group of stakeholders for disaster management and among them armed forces plays a significant role.

The primary role of the armed forces involves to the defence of the country against external and internal threats and needs no deliberation. The secondary role of the armed forces as an "aid of civil authorities" is a constitutional obligation, although as an instrument of last resort. The armed forces can be called out to aid the civil authorities to meet various unforeseen events. It is noted that when any natural or man-made disaster takes place in any part of the world, the armed forces are frequently deployed for disaster risk management.

Currently, involvements of armed forces to aid civil authority in various events are continuously rising. Given their professional training and spirit to deliver and assist the communities, the armed forces always become the first choice of any state civil authorities in the event of disasters. Both the government and civil society have incredible faith in the armed forces and believe that all the emergencies and crisis can be handled by the armed forces effectively. The role of the armed forces in disaster management is globally well recognized. The defence services due to their organization, disposition, training and manpower are natural partners in any national effort to combat disaster. Though, their role in disaster management 
is significant; however their involvement in disaster management has been a debated issue. There are two opposite views on this issue: one opposes the prolonged deployment of the armed forces in disaster relief and the other advocates a larger, proactive and more participative role. This latter view insists on continuing participations of armed forces in disaster relief, rescue and reconstruction.

Therefore, while analyzing disaster management, it is essential to evaluate the role of the armed forces, and the duties of civil administration during the various stages of disaster management. Keeping in the view that the armed forces play an important role in the disaster management it is necessary to analyze and investigate their role in disaster management of India, how they can prove a better disaster manager and how administration can use their services for better disaster risk reduction. Therefore, the basic objective of this paper is to study the role of armed forces in disaster management of India.

\section{Disaster and Disaster Management}

Disaster may be described as a "Catastrophic situation in which the normal pattern of life or ecosystem has been disrupted and extra-ordinary emergency interventions are required to save and preserve lives and or the environment". According to The United Nations International Strategy for Disaster Reduction (UNISDR) 2009 disaster may be defined as " A serious disruption of the functioning of a community or a society involving widespread human, material, economic or environmental losses and impacts, which exceeds the ability of the affected community or society to cope using its own resources." Disasters may be classified into two categories namely: natural disasters and humaninduced disasters. The UNISDR defines disaster risk management as the systematic process of using administrative decisions, organizations, operational skills and capacities to implement policies, strategies and coping capacities of the society and communities to lessen the impacts of natural hazards and related environmental and technological disasters. It comprises all forms of activities, including structural and non-structural measures to avoid (prevention) or to limit (mitigation and preparedness) adverse effects of hazards.

\section{Disaster Vulnerability of India}

India is vulnerable, in varying degrees, to a large number of natural as well as man-made disasters on account of its unique geo-climatic and socioeconomic conditions. It is highly vulnerable to floods, droughts, cyclones, earthquakes, landslides, avalanches and forest fires. Almost 58.6 per cent of the landmass is prone to earthquakes of moderate to very high intensity; over 40 million hectares (12 per cent of land) is prone to floods and river erosion; of the $7,516 \mathrm{~km}$ long coastline, close to $5,700 \mathrm{~km}$ is prone to cyclones and tsunamis; 68 per cent of the cultivable area is vulnerable to drought and hilly areas are at risk from landslides and avalanches. Vulnerability to disasters or emergencies of Chemical, Biological, Radiological and Nuclear (CBRN) origin also exists (National Policy on Disaster Management 2009).

\section{REVIEW OF LITERATURE}

Disaster Management has been a significant issue among policy makers, scientists and social scientists at national and international levels. Consequently, there is a widespread literature available on this issue. It would be fruitful to acquaint the findings of the existing studies undertaken by researchers on the role of armed forces in disaster management. These studies throw light on the problems \& prospects and importance of armed forces in disaster management at national and international levels.

Anderson (1994) confirms that the increasing range and occurrence of disasters has generated global concern and the end of cold war has resulted in a re-orientation of military thinking and the role of military is being redefined particularly in disaster relief. He suggests that further research is required into the establishment of an acceptable and effective relationship between the military and the key civil authorities: the United Nations agencies and the NGOs. Mallick, P K (2007) analyses the role of armed forces in internal security and explains the principles of necessity, minimum forces, impartiality and good faith for armed forces in aid of the civil authority to restore law and order. He pointed out that most of the training in the armed forces is focused towards the primary role (defend external and internal threats). The armed forces are unable to lay adequate stress on training for their secondary role (aid to civil authorities). He concludes that 
the state governments should tackle law and order problems with their own forces and army should only be called when all other avenues available to the state are not sufficient. However, when a terrorist or insurgent threat situation develops, the army should seek to intervene as soon as the threat is noticed. Brancati (2007) tests three different dependent variables (conflict events, level of rebellion and incidence of civil war) and finds that the relationship is strongest for low-level of violence. She finds that earthquakes are significantly related to an increased risk of violent conflicts and among natural disasters; earthquakes are particularly likely to trigger conflict due to their rapid and unpredictable onsets. Nel \& Righarts (2008) using a sample of 183 political units covering the period from 1950 to 2000, find a positive relationship between natural disasters and the risk of armed conflict. Their findings indicate that disasters increase the risk of conflict onset in the same year and the following year.

Raj Alok (2008) concludes while wars occur once in two or three decades, disasters strike with virtual regularity, almost every year, especially in India. The armed forces need to enhance operational capacities, gear up their disaster response further and continue to acquit themselves with distinction when called to aid the civil administration. Further, he observed that there is lack of coordination between the civil administration and armed forces during the disaster management. Dagur (2008) investigates the role of armed forces in disaster management in India and focused on the two different views one view recommends dampening our response and discourages over-enthusiasm, the other recommends a larger, proactive and more participative role in disaster management. He also evaluates the other government agencies like National Disaster Response Forces, Paramilitary Forces and state administration in the process of disaster management and their coordination with armed forces. He admits that motivation, zeal and enthusiasm are much more important than training and equipment for disaster management. However, the organizational values and attitudes cannot be expected to be changed overnight through training and equipment.

Hall (2008) evaluates the engagements between the Japan Self-Defence Forces (JSDF) and Civilian Japan Disaster Relief Teams (CJDRT) during the 2004-2005 tsunami relief operation in Aceh, Indonesia. His study reveals that the asymmetrical field experiences, differential operational structures and procedures, and contrasting timetables of disaster response created tension between JSDF and CJDRT. Moreover, Indonesia had neither legal basis nor established procedures for receiving international relief aid, including foreign military assets. Accordingly, it created more conflict among JSDF, CJDRT and Indonesia authority during tsunami relief work. Kumar (2009) examines the policy framework and organisations for disaster management, the role of NGOs, Communitybased organisations and armed forces in disaster management in Himachal Pradesh with special reference to Mandi district. He observed that there was lack of proper coordination among different agencies or people involved in disaster management in Himachal Pradesh. Moreover the government did not take proper steps for ensuring efficient coordination among them. He states the media plays a vital role for efficient disaster management. Sometimes media creates panic among the people by spreading wrong information about disaster and it creates more trouble for other agencies who are involved in disaster management.

Schnabel and Hristov (2010) state that armed forces around the world are involved in non-traditional roles and tasks beyond their core competence of defending the state from external threats. They conclude that the result of such comparative analyses of armed forces' non-traditional roles and tasks will help us in identifying and understanding the changing purposes of armed forces in the world and then significance to those states that are in the process of redefining and recalibrating the roles of their armed forces. Lele (2011) states that the topography, terrain and climate conditions of the Indian peninsula makes the country more prone to natural disasters. Threats from climate change, epidemics and food and energy insecurity also persist. He shows that the Indian armed forces are guardians of the India's sovereignty and territorial integrity. They also provide significant services during the disasters in India and abroad, and are involved in United Nations peacekeeping operations. He concludes that the Indian armed forces rely on space systems both for strategic and tactical purposes. However, the current level of 
space instruments available for the armed forces are minimal; and, more importantly, they are not specifically designed and developed to satisfy their operational needs. India's space program is still evolving as far as its military requirements are concerned.

Singh (2013) investigates the role of Indian Armed forces in disaster management particular in the case studies of Uttarkashi earthquake-1991, Orissa Cyclone- 1999, Mumbai Attacks 26/11 and management of nuclear disasters in the Indian context. He observed that the efficient armed forces of any country can react quickly and respond rapidly in a full self contained, self sufficient and highly mobile fashion in all situations. Singh also provides some important suggestions for efficient disasters management like need of public awareness, community's participation, effective and realistic disaster management plan and coordination among various people or organizations involved in disaster management. Gautam (2013) discussed the role of Indian military in disaster management and explained that in India, Ministry of Home Affairs is the nodal agency for coordination of relief, response and overall control and regulations of disaster management. However, when any disaster breaks, it is the armed forces under the ministry of defence that is called upon to intervene as an 'aid to civil authority'. He also raises the question as to why most of the time civil administration fails in prevention and preparedness of disaster management.

Mohan (2014) in his study, discussed the Humanitarian Assistance and Disaster Relief of Indian military in India and aboard. First he shows the origin of formation of disaster management mechanism in India and then he focused on humanitarian assistance and disaster relief abroad. He mentions the 'Operation Sukoon-2006"' and 'Operation Blossom-2011' by the Indian armed forces in Lebanon and discussed the tsunami relief operations (2004-05) in Maldives, Sri Lanka and Indonesia. Shabab et al. (2015) analyses the role played by Pakistan armed forces during various disasters and discusses options available to evolve a strategy and organisation, capable of dealing with all types of disasters more effectively and methodically. He explains the existing disaster management structure of Pakistan and exposes that Pakistan armed forces are neither trained nor equipped to undertake such relief operations, yet it has always played an important role with a proactive approach to help the civil machinery overcome natural and manmade disasters in the country. Garge, H Ha and S Khoo (2015) analyze the current state of disaster risk management in India and the role of different government agencies. They discuss how the state governments in India rely on the armed forces to perform their tasks pertaining to disaster risk management. Their study concludes that yet, there is plenty of scope for the civil administration to improve their performance without relying too much on the armed forces in the event of both small and large scale disasters and recommended some solutions to improve the current state of disaster risk reduction. Krishna (2017) identifies areas where lack of coordination between the civil administrations and armed forces adversely affected the performance of the armed forces while providing assistance during the floods in J\&K (2014) and Chennai (2015). Besides, he advocates joint training and mock exercises between civil disaster management machinery and armed forces.

\section{Major Stakeholders of Disaster Management in India}

It is confirmed that no single agency or stakeholders can handle a disaster situation of any scale alone. Different departments or agencies have to work together to manage the disaster with an objective to reduce its impact. Therefore, for efficient disaster management a proper coordination is required among different stakeholders. The main stakeholders of disaster management are the following:

\section{(a) Armed Forces}

The armed forces are called upon to assist the civil administration when the situation is beyond their coping capability. In practice, the armed forces form an important part of the Government's response capacity and are immediate responders in all serious disaster situations. On account of their vast potential to meet any adverse challenge, speed of operational response and the resources and capabilities at their disposal, the armed forces have historically played a major role in emergency support services 
Table 1: Details of Indian Army Deployed Towards Aid to Civil Authority

\begin{tabular}{|c|c|c|c|c|}
\hline \begin{tabular}{|l|} 
Sl. \\
No.
\end{tabular} & Place & Period & Task for Deployed & $\begin{array}{l}\text { No. of Army Columns Deployed and } \\
\text { types of assistance }\end{array}$ \\
\hline 1 & $\begin{array}{l}11 \text { districts of } \\
\text { Haryana }\end{array}$ & $\begin{array}{l}\text { February 19, } 2016 \text { to } \\
\text { February 29, } 2016\end{array}$ & $\begin{array}{l}\text { Maintenance of Law and order } \\
\text { situation during 'Jat agitation' }\end{array}$ & 56 Army Columns \\
\hline 2 & $\begin{array}{l}\text { Pengri, near } \\
\text { Tinsukia district } \\
\text { (Assam) }\end{array}$ & $\begin{array}{l}\text { February 11, } 2016 \text { to } \\
\text { February 14, } 2016\end{array}$ & To Control violent mobs & Three Army Columns \\
\hline 3 & Rajouri (J \& K) & $\begin{array}{l}\text { September 14, } 2016 \text { to } \\
\text { September 21, } 2016\end{array}$ & To Control violent mobs & Three Army Columns \\
\hline 4 & $\begin{array}{l}\text { Flood in River } \\
\text { Tamas, Satna (MP) }\end{array}$ & July 07, 2016 & $\begin{array}{l}\text { Flood relief and rescue } \\
\text { operations in river Tamas }\end{array}$ & $\begin{array}{l}\text { One engineering task force and one army } \\
\text { column, and } 30 \text { civilians rescued }\end{array}$ \\
\hline 5 & $\begin{array}{l}\text { Bongaigaon, Jorhat } \\
\text { (Assam) }\end{array}$ & $\begin{array}{l}\text { July } 08,2016 \text { to } \\
\text { July } 11,2016\end{array}$ & $\begin{array}{l}\text { Flood relief and rescue } \\
\text { operations during Breach in } \\
\text { Bhagdoi Nala }\end{array}$ & One Army Column; 200 civilians rescued \\
\hline 6 & Baran (Rajasthan) & July 11, 2016 & $\begin{array}{l}\text { Flood relief and rescue } \\
\text { operations }\end{array}$ & Two Army Columns; 15 civilians rescued \\
\hline 7 & $\begin{array}{l}\text { Balrampur, Kadwa } \\
\text { and Barsoi villages } \\
\text { of Katihar (Bihar) }\end{array}$ & July 27, 2016 & $\begin{array}{l}\text { Flood relief and rescue } \\
\text { operations }\end{array}$ & $\begin{array}{l}\text { Two Army Columns; } 300 \text { marooned } \\
\text { persons rescued }\end{array}$ \\
\hline 8 & $\begin{array}{l}\text { New Bongaigaon } \\
\text { (Assam) }\end{array}$ & July 26, 2016 & $\begin{array}{l}\text { Flood relief and rescue } \\
\text { operations }\end{array}$ & $\begin{array}{l}\text { One Army Column; } 50 \text { marooned } \\
\text { persons rescued }\end{array}$ \\
\hline 9 & Chirang (Assam) & July 26, 2016 & $\begin{array}{l}\text { Flood relief and rescue } \\
\text { operations }\end{array}$ & $\begin{array}{l}\text { One Army Column; } 190 \text { marooned } \\
\text { persons rescued }\end{array}$ \\
\hline 10 & Pali (Rajasthan) & August 09, 2016 & $\begin{array}{l}\text { Relief and rescue operations } \\
\text { during Heavy rainfall }\end{array}$ & $\begin{array}{l}\text { One Army Column and one engineer } \\
\text { task force; } 34 \text { civilians rescued }\end{array}$ \\
\hline 11 & Kollam (Kerala) & April 10, 2016 & $\begin{array}{l}\text { Relief and rescue operation } \\
\text { during Fire at Puttingal Temple }\end{array}$ & $\begin{array}{l}\text { Two medical teams with all required } \\
\text { equipment }\end{array}$ \\
\hline 12 & $\begin{array}{l}\text { Pukhrayan, } \\
\text { (Kanpur) }\end{array}$ & November 20, 2016 & $\begin{array}{l}\text { Relief and rescue operation } \\
\text { during Indore-Patna express } \\
\text { derailment }\end{array}$ & $\begin{array}{l}\text { Two Army Columns, three medical } \\
\text { teams, one administrative and nine } \\
\text { recovery columns. Five persons rescued } \\
\text { alive, about } 45 \text { bodies recovered. } \\
\text { Provided medical aid and food } \\
\text { distribution. }\end{array}$ \\
\hline 13 & $\begin{array}{l}\text { Karcham } \\
\text { (Himachal Pradesh) }\end{array}$ & June 21, 2016 & $\begin{array}{l}\text { Avoid flood situation in } \\
\text { Artificial lake }\end{array}$ & $\begin{array}{l}\text { One engineering team; Avoided flood } \\
\text { situation }\end{array}$ \\
\hline
\end{tabular}

Source: Annual Report 2016-17, Ministry of Defence, Government of India.

like communication, search and rescue operations, health and medical facilities, and transportation, especially in the immediate aftermath of a disaster. Airlift, heli-lift and movement of assistance to neighbouring countries primarily fall within the expertise and domain of the armed forces. The armed forces will participate in imparting training to trainers and disaster management managers, especially in CBRN aspects, heli-insertion, highaltitude rescue, waterman ship and training of paramedics.

\section{(b) National Disaster Response Force}

The ministry of home affairs raised the NDRF for the purpose of specialized response to disasters or disaster like situations. It was initially constituted in the year 2006 with eight battalions which were stationed in different parts of the country based on the vulnerability profile. At present, it consists of 12 battalions, three each from the Border Security Force (BSF) and Central Reserve Police Force (CRPF) and two each from Central Industrial Security Force (CISF), Indo- Tibetan Border Police (ITBP) and Sashastra Seema Bal (SSB). Each battalion have 18 self-contained specialist search and rescue teams of 45 personnel each including engineers, technicians, electricians, medical and paramedical and dog squads. The total strength of each battalion is 1,149 . 
Table 2: Details of Indian Navy Deployed Towards Aid to Civil Authority

\begin{tabular}{|c|c|c|c|c|}
\hline $\begin{array}{l}\text { S1. } \\
\text { No. }\end{array}$ & Place & Period & Reasons for Deployed & No. of Navy Columns and types of assistance \\
\hline 1 & Kollam (Kerala) & $\begin{array}{l}\text { April 10, } \\
2016\end{array}$ & $\begin{array}{l}\text { Relief and rescue } \\
\text { operation during Fire } \\
\text { incident at Puttingal } \\
\text { Temple }\end{array}$ & $\begin{array}{l}\text { Two advanced light helicopters with a nine member medical } \\
\text { team along with supplies and equipment. Indian Navy Ships } \\
\text { Sunayan, Kabra and Kalpeni with } 400 \mathrm{Kgs} \text { of medical supplies } \\
\text { reached Kollam on the same day. }\end{array}$ \\
\hline 2 & $\begin{array}{l}\text { Duvvada SEZ, } \\
\text { Visakhapatnam }\end{array}$ & $\begin{array}{l}\text { April 26, } \\
2016\end{array}$ & $\begin{array}{l}\text { Relief and rescue } \\
\text { during Fire incident at } \\
\text { Visakhapatnam }\end{array}$ & $\begin{array}{l}\text { Nine Naval fire tenders, two medical teams with ambulances } \\
\text { and Naval Quick Reaction Teams. Additionally, Dornier aircraft } \\
\text { carried out aerial recce of the fire affected area and Chetak } \\
\text { helicopters dropped dry chemical powder Fire Extinguishing } \\
\text { Balls to assist in extinguishing the fire. }\end{array}$ \\
\hline 3 & $\begin{array}{l}\text { Kiltan and } \\
\text { Agatti islands } \\
\text { ( L \& M Islands) }\end{array}$ & $\begin{array}{l}\text { June 24, } \\
2016\end{array}$ & Medical evacuation & $\begin{array}{l}\text { One Cornier and Advanced Light Helicopters for medical } \\
\text { evacuation of critical patients from Kiltan and Agatti islands to } \\
\text { Kochi }\end{array}$ \\
\hline 5 & $\begin{array}{l}\text { Mahad, } \\
\text { Raigarh district } \\
\text { Maharashtra }\end{array}$ & $\begin{array}{l}\text { August 03, } \\
2016 \text { to } \\
\text { August } 14 \\
2016\end{array}$ & $\begin{array}{l}\text { Diving assistance for } \\
\text { missing personnel } \\
\text { during a bridge } \\
\text { collapsed on Savitri } \\
\text { river due to heavy rain }\end{array}$ & $\begin{array}{l}\text { Diving team of } 22 \text { personnel with three Gemini craft and Two } \\
\text { king helicopters. Recovery of two state government buses, and } \\
\text { SUV and } 14 \text { bodies drowned in the river }\end{array}$ \\
\hline
\end{tabular}

Source: Annual Report 2016-17, Ministry of Defence, Government of India.

Table 3: Details of Indian Air Force Deployed Toward Aid to Civil Authority

\begin{tabular}{|l|l|l|l|l|}
\hline $\begin{array}{l}\text { S1. } \\
\text { No. }\end{array}$ & Place & Period & Reasons for Deployed & Types of assistance \\
\hline 1 & J \& K & $\begin{array}{l}\text { July 09, 2016 to } \\
\text { August 09, 2016 }\end{array}$ & $\begin{array}{l}\text { Maintenance of Law and order } \\
\text { situation during agitation. Airlift } \\
\text { Central Para Military Force from } \\
\text { various part of country to Srinagar }\end{array}$ & $\begin{array}{l}\text { A total of 7184 troop and 299.3 ton load } \\
\text { airlifted }\end{array}$ \\
\hline 2 & Bihar Flood & $\begin{array}{l}\text { August 20, 2016 to } \\
\text { August 23,2016 }\end{array}$ & $\begin{array}{l}\text { Airlift NDRF teams from Arakkonam, } \\
\text { Bhubaneshwar and Bhatinda to Bihar }\end{array}$ & $\begin{array}{l}\text { A total of 539 NDRF personnel and 27.3 ton } \\
\text { load airlifted }\end{array}$ \\
\hline 3 & $\begin{array}{l}\text { Fire in 11 } \\
\text { district of } \\
\text { Uttarakhand }\end{array}$ & $\begin{array}{l}\text { April 30, 2016 to } \\
\text { May 08, 2016 }\end{array}$ & $\begin{array}{l}\text { Aerial fire fighting by deploying Mi } \\
\text { 17 V5 helicopters. }\end{array}$ & $\begin{array}{l}\text { IAF helicopters flew 95 sorties under } \\
\text { challenging conditions and saved valuable } \\
\text { life, property and natural resources. }\end{array}$ \\
\hline
\end{tabular}

Source: Annual Report 2016-17, Ministry of Defence, Government of India.

Table 4: Details of Indian Coast Guard Deployed Towards Aid to Civil Authority

\begin{tabular}{|l|l|l|l|}
\hline $\begin{array}{l}\text { S1. } \\
\text { No. }\end{array}$ & Place & Period & Reasons for Deployed and types of assistance \\
\hline 1 & $\begin{array}{l}\text { Rescue of stranded personnel in } \\
\text { Daman Ganga River, Silvasa }\end{array}$ & July 02, 2016 & $\begin{array}{l}\text { Coast Guard Helicopter ex Daman airlifted and rescued Ten } \\
\text { personnel trapped in Daman Ganga River bordering Silvasa. }\end{array}$ \\
\hline 2 & $\begin{array}{l}\text { Rescue of stranded personnel in } \\
\text { Auranga river at Valsad (Gujarat) }\end{array}$ & $\begin{array}{l}\text { August 02, } \\
2016\end{array}$ & $\begin{array}{l}\text { Two Coast Guard Helicopters ex Daman rescued 28 stranded } \\
\text { personnel. }\end{array}$ \\
\hline 3 & $\begin{array}{l}\text { Assistance to Vessels inside the } \\
\text { Jawahar Dock, Chennai Harbour, } \\
\text { Chennai }\end{array}$ & $\begin{array}{l}\text { December 12, } \\
2016\end{array}$ & $\begin{array}{l}\text { During landfall of cyclonic storm 'Vardah', Indian Cost Guard Ship } \\
\text { provided berthing assistance to distressed vessels at Jawahar Dock. }\end{array}$ \\
\hline
\end{tabular}

Source: Annual Report 2016-17, Ministry of Defence, Government of India. 
All the 12 battalions have been equipped and trained to respond natural as well as man-made disasters. These battalions are also trained and equipped for response during CBRN emergencies. Since, its inception it has continued to win hearts of millions of countrymen, by demonstrating its expertise and compassion while handling disaster situations. These battalions are located at 12 different locations in the country based on the vulnerability profile of country and to cut down the response time for their deployment at disaster site.

\section{(c) Central Armed Police Forces}

The Central Armed Police Forces (BSF, CRPF, CISF, ITBP and SSB), which are also the significant force of the Union, play a key role at the time of immediate response to disasters. Besides contributing to the NDRF, they will develop adequate disaster management capabilities within their own forces and respond to disasters which may occur in the areas where they are posted.

\section{(d) Other Important Stakeholders of Disaster Management}

Indian Cost Guard, State Disaster Response Force, State Police Forces, Fire Services, Civil Defence, Home Guards, Central Paramilitary Forces, Border Road Organisation, National Cadet Corps, National Service Scheme, NGO, Self Help Groups and other volunteers' organisation are crucial and immediate responders to disasters and play an important role in disaster management. Further, these stakeholders are very suitable to support all community-based initiatives in disaster management and are very important instantaneous manager of disaster management.

\section{Indian Armed Forces Major Assistance to Civil Authority during 2016}

The Indian armed forces are one of the most dedicated, professional and modernized armed forces in the world. They have made rapid strides in technology development and are adequately equipped with the necessary technical competence, manpower and material resources to undertake any scale of disaster rescue and response operations. The Indian Armed Forces render timely assistance to civil authorities under "Defence Service Regulations" for the maintenance of law and order, maintenance of essential services, assistance during natural calamities, and any other types of assistance which may be needed by the civil authorities. The details of assistance provided by the Indian armed forces during the period 2016-17 are given in the Table 1 to 4 .

\section{CONCLUSION AND SUGGESTIONS}

The armed forces due to their organization, training, manpower and dedications are playing a significant role in disaster management. Their ability to work under adverse ground and climatic conditions is an unusual attribute to help to civil authority during disasters. Government, civil society and all other stakeholders have incredible faith and believe that all types of disaster can be efficiently handled by the armed forces. The Indian armed forces are one of the most dedicated professional and modernized armed forces in the world. They are always in a state of operational readiness to move quickly to any disaster affected area. Besides, NDRF also played an important role in rescue and relief operation in all major disasters in the country; in fact their service during the disasters reduces the pressure on the armed forces. The armed force will continue to play a vital role in disaster response as they are the core of the government's response capacity in major disaster situations.

The armed forces should be deployed only in such situations which are beyond the managing capabilities of the civilian administration and deployment should not for long period, more dependence on armed forces for disaster management is not in favor of a country and thus should be minimized. For efficient utilization of armed forces services in disaster management, a proper coordination among different stakeholders is prerequisite. To achieve this first all stakeholders should be included in the process of making disaster management plans at all levels and second all stakeholders should be included in the joint exercises for disaster management. Consequently, it will reduce the conflicts and confusion among different stakeholders, which are the keys obstacles in the various phases of disaster management. Disaster management training should be an important part of armed forces training, newly posted armed forces in a particular area should be trained and updated about vulnerability and disaster management plan 
of the areas. However, there is need to reduce the pressure on armed forces, for this specialized forces similar to NDRF should be created or NDRF itself should be strengthened further.

\section{REFERENCES}

Alexander, David. 2006. Globalization of Disaster: Trends, Problems and Dilemmas. Journal of International Affairs, Spring / Summer, 59(2): 1-22.

Anderson, E.W. 1994. Disaster Management and the Military, GeoJournal, 34(2): 201-205.

Brancati, Dawn. 2007. Political aftershocks: The Impact of Earthquakes on Intrastate Conflict. Journal of Conflict Resolution, 51(5): 715-743.

Col. Deshbir Singh. 2013. Select Case Studies of Disaster Management in India and the Role of Indian Armed Forces, Department of Defence and Strategic Studies, Bhonsala Military College, Nasik, University of Pune, Pune.

Col. OS, Dagur. 2008. Armed Forces in Disaster ManagementA Perspective on Functional Aspects of Role, Training and Equipment. Manekshaw Paper, 4: 1-38.

Garge Ramanand N, Huong Ha and Susie, Khoo. 2015. Disaster Risk Management and the Role of the Armed Forces: Critical Analysis of Reactive Disaster Management in India. in Strategic Disaster Risk Management in Asia, Edited by Huong Ha, R. Lalitha S Fernando and Amir Mahmood, Springer, New Delhi, pp. 49-68.

Gautam, P.K. 2013. Role of the Indian Military in Disasters, Institute for Defence Studies and Analyses, New Delhi.

Hall, Rosalie Arcala. 2008. Civil-Military Cooperation in International Disaster Response: The Japanese SelfDefense Forces' Deployment in Aceh, Indonesia. Korean Journal of Defence Analysis, 20(4): 383-400.

John. Y .Schrader. 1993. The Army's Role in Domestic Disaster Support- An Assessment of Policy Choices, RAND, CA, United States.

Krishna, Amar and Parmod, Damle. 2017. Armed Forces in Disaster Management in India: Need for Improving Civil - Military Coordination. International Journal of Innovative Research in Science, Engineering and Technology, 6(7): 13238-13243.

Kumar, Ganesh. 2017. An Analysis of International Arms Transfer in Contemporary World. JIM QUEST Journal of Management and Technology, 13(2): 54-61.
Kumar, Vinod. 2009. Disaster Management in Himachal Pradesh: a Study of Mandi District, (Ph.D thesis), Department of Public Administration, Himachal Pradesh University, Shimla.

Lele, Ajey. 2011. Indian Armed Forces and Space Technology. Indian Review, 10(4): 379-393.

Mallick, P K. 2007. Role of the Armed Forces in Internal Security: Time for Review. CLAWS Journal, Winter 2007, pp. 68-90.

Mohan, C Raja. 2014. Indian Military Diplomacy: Humanitarian Assistance and Disaster Relief. Institute of South Asian Studies, National University of Singapore, Singapore, Working Paper, No. 184.

National Disaster Management Authority. 2009. National Policy on Disaster Management-2009, Government of India, New Delhi.

National Disaster Management Authority. 2016. National Disaster Management Plan- 2016. Government of India, New Delhi.

National Institute of Disaster Management. 2014. Uttarakhand Disaster-2013.

Nel, Philip and Marjolein Righarts. 2008. Natural Disasters and The Risk of Violent Civil Conflict. International Studies Quarterly, 52(1): 159-185.

Raj, Alok. 2008. Armed Forces in Disaster Response: Role Reappraisal. CLAWS Journal, pp. 163-182.

Shabab, Raja, Arshad Ali, Shahid Iqbal and Maqbol Sadiq Awan. 2015. Armed Forces and Disaster Management. American Journal of Social Science Research, 1(3): 152-157.

Schnabel, Albrecht and Hristov, Danail. 2010. Conceptualising Non-Traditional Roles and Tasks of Armed Forces. Security and Peace, 28(2): 73-80.

Singh, Deshbir. 2013. Select Case Studies of Disaster Management in India And The Role of Indian Armed Forces, (Ph.D thesis), Department of Defence and Strategic Studies, Bhonsala Military College, Nasik, University of Pune.

UNISDR. 2016. Sendai Framework for Disaster Risk Reduction 2015-2030.

United Nations International Strategy for Disaster Reduction. 2009. 2009-UNISDR Terminology on Disaster Risk Reduction, United Nations, Geneva, Switzerland. 